Sains Malaysiana 49(8)(2020): 1765-1771

http://dx.doi.org/10.17576/jsm-2020-4908-01

\title{
Accumulation and Phytoextraction Potential of Heavy Metals of Enhalus acoroides in The Coastal Waters of Lamongan, Java, Indonesia
}

(Penumpukan dan Potensi Fotopengekstrakan Logam Berat terhadap Enhalus acoroides di Perairan Pinggir Laut Lamongan, Java, Indonesia)

\author{
DEFri YONA*, SYARIFAH HikMAH JUlindA SARI \& RUli HikMAH SAFITRI
}

\begin{abstract}
This study quantified the concentration of heavy metals $\mathrm{Cd}$ and $\mathrm{Cu}$ in Enhalus acoroides from shallow seagrass habitat in the northern coastal waters of Lamongan, Indonesia. The objective of this study was to determine the concentration of these metals in different parts of seagrass E. acoroides and to assess their biomonitoring potential of heavy metals pollution in coastal areas. Heavy metal contents in the sediments, roots and leaves of E. acoroides were determined by Flame Atomic Absorption Spectrometry from four sampling sites. The results showed that the concentrations of $\mathrm{Cu}$ were significantly higher than the concentrations of $\mathrm{Cd}$ in both sediments and seagrass tissues in all stations. The concentrations of $\mathrm{Cu}$ were found in slightly similar values in the sediments, roots and leaves. On the other hand, the concentrations of $C d$ were higher in the sediments than in the roots and leaves of $\mathrm{E}$. acoroides. In addition, Bioconcentration Factor (BCF) of $C u$ in E. acoroides was two times higher than $B C F$ of $C d\left(B C F_{C u}=1.09 ; B C F_{C d}=\right.$ 0.49). In contrast, Translocation Factor (TF) of $C u$ was lower than TF of $C d$ that was 0.65 and 1.05, respectively. According to BCF and TF values, E. acoroides can be considered to have the ability to perform phytoextraction process especially $C d$ because E. acoroides was able to restrict its absorption of Cd from the environment $(B C F<1)$ and once it is absorbed, the plant has the ability to transfer it to the other body parts (TF > 1).
\end{abstract}

Keywords: Coastal waters; heavy metal pollution; Indonesia; Lamongan; phytoextraction; seagrass

ABSTRAK

Kajian ini mengukur kepekatan logam berat $\mathrm{Cd}$ dan $\mathrm{Cu}$ dalam Enhalus acoroides dari habitat lamun yang cetek di perairan utara pinggir laut Lamongan, Indonesia. Objektif kajian ini adalah untuk menentukan kepekatan logam ini pada bahagian lamun E. acoroides yang berbeza dan untuk menilai potensi pembioawasannya terhadap pencemaran logam berat di perairan pinggir laut. Kandungan logam berat dalam sedimen, akar dan daun E. acoroides ditentukan melalui Spektrometri Nyala Penyerapan Atom daripada keempat-empat sampel. Hasil kajian menunjukkan bahawa kepekatan Cu adalah lebih tinggi daripada kepekatan Cd dalam kedua-dua sedimen dan tisu lamun dalam semua stesen. Kepekatan Cu adalah lebih kurang sama dalam sedimen, akar dan daun. Sebaliknya, kepekatan Cd adalah lebih tinggi pada sedimen berbanding akar dan daun E. acoroides. Tambahan lagi, Faktor Pembiopekatan (BCF) $C u$ dalam E. acoroides adalah dua kali ganda lebih tinggi daripada $B C F C d\left(B C F_{C u}=1.09 ; B C F_{C d}=0.49\right)$. Faktor Translokasi (TF) Cu pula adalah lebih rendah berbanding TF Cd, iaitu 0.65 dan 1.05. Menurut nilai BCF dan TF, E. acoroides boleh dianggap mempunyai kemampuan untuk melakukan proses fotopengekstrakan, terutamanya Cd kerana E. acoroides boleh menyekat penyerapan Cd daripada persekitaran $(B C F<1)$ dan setelah ia terserap, tumbuhan mempunyai keupayaan untuk memindahkannya ke bahagian yang lain (TF > 1).

Kata kunci: Fotopengekstrakan; Indonesia; Lamongan;lamun; pencemaran logam berat; perairan pinggir laut

\section{INTRODUCTION}

Seagrasses play significant roles in coastal ecosystems and are exposed to a wide variety of pollutants including heavy metals (Brown et al. 2016; Govers et al. 2014; Thangaradjou et al. 2010). There have been many studies on the accumulation of heavy metals in the seagrass ecosystems (Riosmena-Rodríguez et al. 2010; Schlacher-Hoenlinger \& Schlacher 1998a; Suwandana et al. 2011; Thangaradjou et al. 2013). Depending on the species, seagrass can accumulate heavy metals differently (Thangaradjou et al. 2010) due to the differences in the metabolic condition and life stage of the individual species (Riosmena-Rodríguez et al. 2010).

Seagrass absorbs heavy metals and store it in the above ground parts (shoots and leaves) and below ground parts (roots). Above ground and below ground parts could have significant differences in accumulating heavy metals. Lin et al. (2016) in their study of Zostera 
japonica found a higher accumulation of $\mathrm{Cu}$ and $\mathrm{Cd}$ in the above ground parts, while the accumulations of $\mathrm{Hg}$ and As were higher in the below ground parts. This could be the result of differences in the metals uptake routes into seagrass from sediment to root/rhizome and from water to leaf/epiphyte pathways (Schlacher-Hoenlinger \& Schlacher 1998b).

The ability of seagrass to accumulate heavy metals can be used to reduce metal pollution in the environment through phytoremediation process. There have been many studies conducted to evaluate the ability of plants in reducing metal pollution through phytoremediation process (Bonanno et al. 2017; Hidayati et al. 2009; Sari et al. 2018; Sidi et al. 2018). Yoon et al. (2006) identify two types of applications of phytoremediation in plants: phytoextraction, i.e. metal uptake and accumulation into plant shoots which can be harvested and removed from the ecosystems; and phytostabilization, i.e. the use of plants to minimize metal mobility in the contaminated areas. Bio-concentration factor (BCF) and translocation factor $(\mathrm{TF})$ can be used as an indicator to estimate plant's potential for phytoremediation purpose. BCF is the ratio of metal concentration in the roots to that in the soil, while TF is the ratio of metal concentration in the shoots/ leaves to the roots.

Indonesia as part of Southeast Asia is famous for the greatest diversity of seagrasses (Ooi et al. 2011). This ecosystem can act as a sink for pollutants in the coastal environment (Schlacher-Hoenlinger \& Schlacher 1998b; Sidi et al. 2018). Lamongan is known as one of the busiest harbors in East Java, with high activities in fisheries and industries. These activities could have a significant impact on the ecosystems by the contribution of pollutant such as heavy metals. E. acoroides can be found along the northern coastal waters of Lamongan and the ecosystem is vulnerable to pollutants. Therefore, this study aimed to estimate metal concentrations $(\mathrm{Cu}$ and $\mathrm{Cd}$ ) in the sediment, roots and leaves of Enhalus acoroides and to determine its ability in conducting phytoremediation process of heavy metals from the seagrass ecosystem in the northern coastal waters of Lamongan, Indonesia.

\section{MATERIALS AND METHODS}

\section{STUDY AREA AND SAMPLING METHOD}

Sampling was conducted in the northern coastal waters of Lamongan, East Java Province. There were four sampling stations chosen to collect sediment and seagrass samples. All sampling stations were characterized by the presence of pollutants from fisheries and domestic activities. Station 1 was located near Brondong Harbor which is busy with its fishery activity and Stations 2, 3 , and 4 were located near residential areas with high contribution of the pollutant from domestic activities (Figure 1).
Sample collection was conducted in March 2016. Sediment samples were collected at $30-35 \mathrm{~cm}$ from the surface using $50 \mathrm{~cm}$ long and $5 \mathrm{~cm}$ in diameter of PVC core sampler. About $1 \mathrm{~kg}$ of sediment was taken and placed in a sealed plastic bag. Seagrass samples were taken by collecting the roots and leaves and rinsed with seawater to remove residue and epiphytes that attached to it. The roots and leaves were then placed in plastic bags. All the samples (seagrass and sediments) were collected in duplicate. Sediment and seagrass samples were put in an icebox to be transported to the laboratory for further analysis.

\section{SAMPLE ANALYSIS}

Sediment and seagrass samples analysis were conducted according to Lin et al. (2016) and Nguyen et al. (2017). Sediment samples were dried to constant weight at room temperature and once dried the samples were passed through a $1 \mathrm{~mm}$ diameter sieve. A $1 \mathrm{~g}$ quantity of dry sediment samples were oven digested at $90{ }^{\circ} \mathrm{C}$ overnight in an acid solution $\left(\mathrm{H}_{2} \mathrm{O}_{2} / \mathrm{HNO}_{3}, 2: 3 \mathrm{v} / \mathrm{v}\right.$ ratio). After digestion, the samples were diluted with Milli-Q water to final volume of $25 \mathrm{~mL}$ and analyzed for the $\mathrm{Cu}$ and $\mathrm{Cd}$ contents using a Shimadzu Flame Atomic Absorption Spectrophotometer Model AA-6800.

Seagrass samples were cut off using non-metal or ceramics scissors and dried at room temperature. Once dried, the samples were ground and homogenized in an agate mortar. Sample digestions were conducted by adding acid solution similar to sediments sample digestion process and the heavy metal concentrations were measured using FAAS. Quality assurance procedures for all samples were conducted using blank and standard solutions by developing calibration curves.

\section{DATA ANALYSIS}

Bioconcentration factor $(\mathrm{BCF})$ and translocation factor (TF) were used to analyze phytoremediation potential of E. acoroides. BCF was calculated from the ratio of metal concentration in the root and the concentration in the sediments, meanwhile, the ratio of metal concentration in the root and in the leaf was used to determine TF (Hu et al. 2019). Significant differences in metal concentration between sampling stations and concentrations of metal in sediment and seagrass tissues were determined using a two-way analysis of variance (ANOVA). Statistical tests were assessed at the significant values of 0.05 and carried out with SPSS 16.0 for Windows.

\section{RESULTS AND DISCUSSION}

\section{METAL CONCENTRATIONS AND DISTRIBUTIONS IN SEDIMENTS AND SEAGRASS TISSUES}

At all sampling stations, the mean concentrations of $\mathrm{Cu}$ were higher than the concentrations of $\mathrm{Cd}$ in 
both the sediments and seagrass tissues (Figure 2). $\mathrm{Cu}$ concentrations in the sediments, roots and leaves were in the range of $0.20-0.31 \mu \mathrm{g} \mathrm{g}^{-1}, 0.01-0.45 \mu \mathrm{g} \mathrm{g}^{-1}$ and $0.01-$ $0.67 \mu \mathrm{g} \mathrm{g}^{-1}$ in all sampling stations, respectively. On the other hand, the concentrations of $\mathrm{Cd}$ were in the range of $0.07-0.12 \mu \mathrm{g} \mathrm{g}^{-1}$ in the sediments, $0.01-0.06 \mu \mathrm{g} \mathrm{g}^{-1}$ in the roots, and $0.01-0.07 \mu \mathrm{g} \mathrm{g}^{-1}$ in the leaves in all sampling stations. The results of this study were very much lower compared to the study of Ismarti et al. (2017), Nguyen et al. (2017) and Sidi et al. (2018). In addition, compared to the study conducted by Sugiyanto et al. (2016) in Pantai Paciran, Lamongan, Cd concentrations in the sediment found in this study were higher, but the concentrations in the seagrass roots and leaves were found rather low.

A two-way ANOVA test showed that the distributions of $\mathrm{Cu}$ has no significant difference among sampling stations $(\mathrm{p}=0.37)$ and also among sediment and seagrass tissues ( $p=0.72$ ). $\mathrm{Cu}$ concentrations were found very much alike in all sampling stations for sediments, roots, and leaves of seagrass (Figure 2A). By using similar statistical analysis, no significant difference of Cd concentration between sampling stations $(p=0.07)$. However, this study detected a significant difference in the mean of $\mathrm{Cd}$ concentrations among sediments, roots, and leaves of seagrass $(p<0.05)$. Cd concentrations in the sediments were higher than in the roots and leaves (Figure 2B). Moreover, the concentrations of $\mathrm{Cd}$ in seagrass tissues were found mostly higher in the leaves than in the roots (Figure 2B). Above ground tissue of seagrass tend to accumulate a higher level of $\mathrm{Cd}$ compared to underground tissues. A study reported by Bonanno and Martino (2017) and Llagostera et al. (2011) also showed the same findings using seagrass $P$. oceanica and $C$. nodosa, respectively. Leaves of seagrass accumulated metals including $\mathrm{Cd}$ not only from roots translocation but also perform a higher absorption rate of the dissolved metals from surrounding waters (Rosalina et al. 2019; Zakhama-Sraieb et al. 2015). This result also indicated that there is a removal strategy conducted by seagrass species by storing the amount of metals in the leaves and then performed metal reduction because of a high rate of alteration in the leaves of seagrass (Bonanno \& Martino 2017).

\section{METAL ACCUMULATIONS IN Enhalus acoroides}

The accumulations of $\mathrm{Cu}$ and $\mathrm{Cd}$ in the seagrass tissues were observed from $\mathrm{BCF}$ and $\mathrm{TF}$ values and it shows two categories (Table 1). According to Yoon et al. (2006), $\mathrm{BCF}$ and $\mathrm{TF}<1$ means that the plant is not optimal to do phytoextraction process, while $\mathrm{BCF}$ and $\mathrm{TF}>1$ shows the ability of the plant to conduct phytoextraction. Phytoextraction is the ability of plants to transfer pollutants to its other body parts such as shoots or leaves that can be harvested, thus reducing the level of pollutant in the environment.

$\mathrm{BCF}>1$ shows the concentration of metal is higher in the roots than the concentration in the sediments. $E$. acoroides in this study shows $\mathrm{BCF}>1$ for $\mathrm{Cu}$ in almost all sampling stations, except at Station 3. On the other hand, the concentrations of $\mathrm{Cd}$ in the roots of $E$. acoroides were lower than the concentration of $\mathrm{Cd}$ in the sediments, resulted in the low value of $\mathrm{BCF}(<1)$ in all sampling stations. $\mathrm{Cu}$ is one of the essential metals (Bastami et al. 2014; Saher \& Siddiqui 2016; Sari et al. 2018) and that can be the reason of high absorption of the metal in $E$. acoroides, unlike $\mathrm{Cd}$ that is categorized as non-essential metal which the biological function is still unknown. A similar result has been found in the study of AmboRappe et al. (2011) on the impact of metal exposure to the growth and leaf asymmetry of Halophila ovalis. Their study observed that the growth of $H$. ovalis is related to the ability of the plants to include or exclude the metals in relation to its function in the metabolic process. Plants tend to absorb more essential metals such as $\mathrm{Cu}$ and resulted in the toxicity even at a lower concentration, while $\mathrm{Cd}$ as a non-essential metal that is not required for growth is actively excluded in the absorption process by plants.

Station 3 is the only station in the study areas with $\mathrm{BCF}<1$ for $\mathrm{Cu}$ and this is related to the low concentration of $\mathrm{Cu}$ in the sediment of Station 3. Sampling at Station 3 was conducted in the water that is connected to the open sea that influenced the accumulation of the metal in the sediment (Lin et al. 2013). This result is supported by the study of Ali et al. (2016) that found the increasing concentration of heavy metals in the sediment during low water movement. Low concentration of $\mathrm{Cu}$ in the sediments resulted in the low concentration of $\mathrm{Cu}$ in the roots and eventually lowering the value of BCF. Even though BCF at Station 3 was less than 1, but the TF value was the highest (1.99) among other sampling stations. TF value $>1$ shows the ability of plants to transfer pollutant from the roots to the other body parts. All stations, except Station 2, were observed to have TF $>1$ for $\mathrm{Cu}$. These differences might be the result of the metal transfer mechanisms from the environment to the plants due to the difference in the seagrass morphology (Bonanno et al. 2017; Schlacher-Hoenlinger \& Schlacher 1998b).

$E$. acoroides has the ability to do phytoextraction process of $\mathrm{Cd}$, as can be seen from the BCF values that are less than one in all sampling stations and $\mathrm{TF}$ values that are more than 1 in most stations (Table 1). BCF less than one shows E. acoroides restricted the absorption of $\mathrm{Cd}$ from the environment. However, once the metal is absorbed, the plants will optimize its ability to transfer the metal to other body parts, in this case is leaves (TF $>$ 1). This mechanism can be used to reduce $\mathrm{Cd}$ level in the water and plants because the leaves that have contained metals then can be harvested (Timofeeva et al. 2017; Van der Ent et al. 2020; Yoon et al. 2006). Moreover, plants have the ability to actively exclude metals that are not required for growth or development to minimize toxicity by isolating it in the storage tissues, where it does not interfere with the metabolic activity (Ambo-Rappe et al. 2011). 
A comparison of the accumulation process of $\mathrm{Cu}$ and cadmium in different seagrass species between this study and other studies from different geographical areas is summarized in Table 2. Bioconcentration and translocation values in this study were very much lower compared to those studies especially for $\mathrm{Cd}$. Similar results were observed for the bioconcentration factor of $\mathrm{Cu}$ in E. acoroides (Nguyen et al. 2017) and Z. japonica (Lin et al. 2016). These differences might be the result of the variability in the physical and chemical factors, plant morphology and also metal contaminants between different study areas.

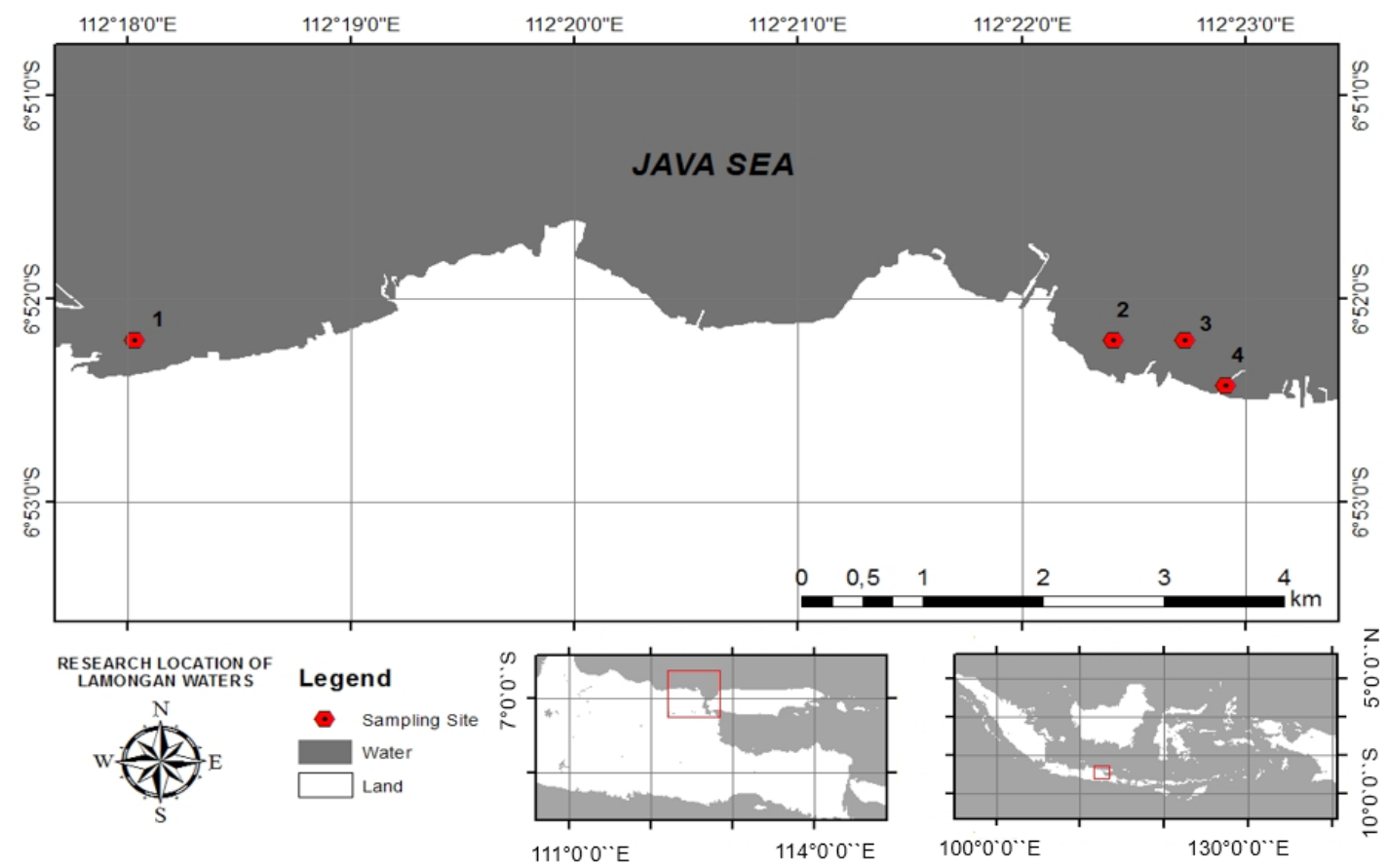

FIGURE 1. Map of the sampling sites in the northern coastal water of Lamongan, Indonesia
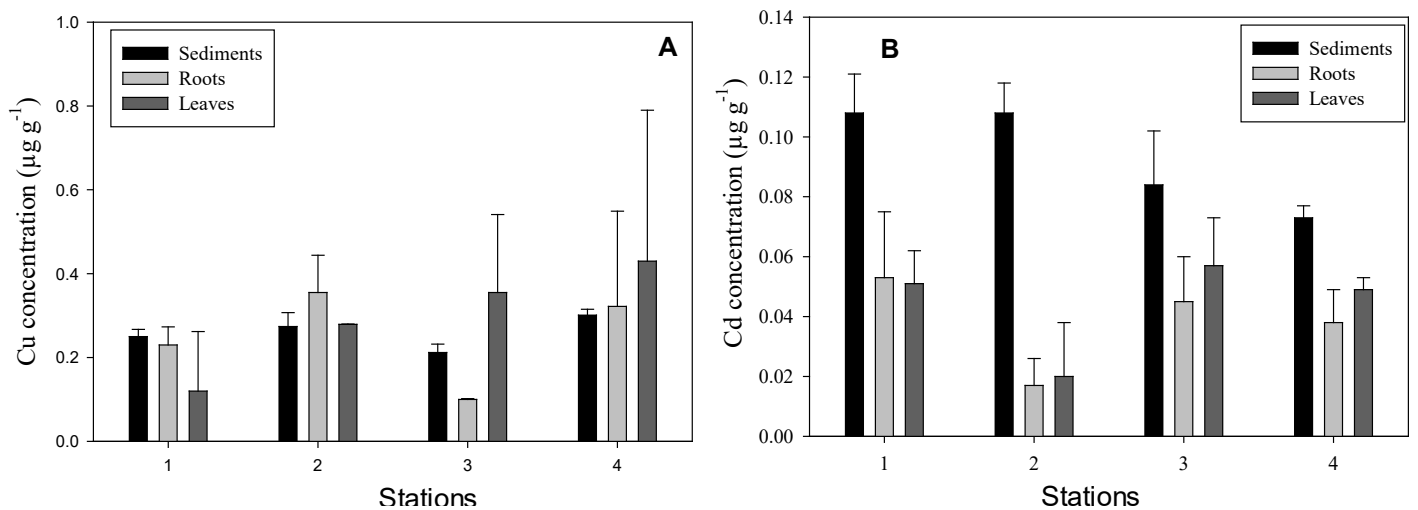

FIGURE 2. The metal concentrations of $\mathrm{Cu}(\mathrm{A})$ and $\mathrm{Cd}(\mathrm{B})$ in the sediments, roots and leaves of $E$. acoroides in the northern water of Lamongan, Indonesia 
TABLE 1. BCF and TF of $\mathrm{Cu}$ and $\mathrm{Cd}$ in E. Acoroides

\begin{tabular}{lcccc}
\hline & \multicolumn{4}{c}{ Station } \\
\cline { 2 - 5 } & 1 & 2 & 3 & 4 \\
\hline $\mathrm{BCF}$ & 1.08 & 1.18 & 0.40 & 1.17 \\
$\mathrm{TF}$ & 1.54 & 0.73 & 1.99 & 1.34 \\
$\mathrm{Cd}$ & & & & \\
$\mathrm{BCF}$ & 0.49 & 0.16 & 0.53 & 0.52 \\
$\mathrm{TF}$ & 0.95 & 1.15 & 1.27 & 1.29 \\
\hline
\end{tabular}

TABLE 2. Bioconcentration (root to sediment) and translocation factors (leaf to root) of different seagrass species reported from other studies

\begin{tabular}{|c|c|c|c|c|c|c|}
\hline \multirow[t]{2}{*}{ Species } & \multirow[t]{2}{*}{ Location } & \multicolumn{2}{|c|}{$\mathrm{Cu}$} & \multicolumn{2}{|c|}{$\mathrm{Cd}$} & \multirow[t]{2}{*}{ References } \\
\hline & & $\mathrm{BCF}$ & $\mathrm{TF}$ & $\mathrm{BCF}$ & $\mathrm{TF}$ & \\
\hline $\begin{array}{l}\text { Enhalus } \\
\text { acoroides }\end{array}$ & $\begin{array}{l}\text { Northern water } \\
\text { of Lamongan, } \\
\text { Indonesia }\end{array}$ & $0.4-1.18$ & $0.73-1.99$ & $0.16-0.53$ & $0.95-1.29$ & This study \\
\hline $\begin{array}{l}\text { Enhalus } \\
\text { acoroides }\end{array}$ & $\begin{array}{c}\text { Merambong } \\
\text { Shoal, Johor } \\
\text { Strait }\end{array}$ & - & 2.6 & - & 5.8 & $\begin{array}{l}\text { (Sidi et al. } \\
\text { 2018) }\end{array}$ \\
\hline $\begin{array}{l}\text { Enhalus } \\
\text { acoroides }\end{array}$ & $\begin{array}{c}\text { Coast of Khanh } \\
\text { Hoa, Vietnam }\end{array}$ & $0.1-0.9$ & - & $3.7-9.3$ & - & $\begin{array}{c}\text { (Nguyen et al. } \\
2017 \text { ) }\end{array}$ \\
\hline $\begin{array}{l}\text { Enhalus } \\
\text { acoroides }\end{array}$ & $\begin{array}{l}\text { Paciran Beach, } \\
\text { Lamongan, } \\
\text { Indonesia }\end{array}$ & - & - & 3.74 & 1.19 & $\begin{array}{c}\text { (Sugiyanto et } \\
\text { al. 2016) }\end{array}$ \\
\hline $\begin{array}{l}\text { Cymodocea } \\
\text { nodosa }\end{array}$ & Sicily, Italy & 2.44 & 1.07 & 1.30 & 0.87 & $\begin{array}{c}\text { (Bonanno \& } \\
\text { Di Martino } \\
\text { 2016) }\end{array}$ \\
\hline $\begin{array}{l}\text { Posidonia } \\
\text { oceanica }\end{array}$ & Sicily, Italy & 4.15 & 0.54 & 5.21 & 1.34 & $\begin{array}{l}\text { (Bonanno et } \\
\text { al. 2017) }\end{array}$ \\
\hline $\begin{array}{l}\text { Posidonia } \\
\text { australis }\end{array}$ & & 0.35 & 0.53 & 3.27 & 0.85 & \\
\hline $\begin{array}{l}\text { Cymodocea } \\
\text { nodosa }\end{array}$ & & 2.96 & 1.11 & 1.89 & 1.08 & \\
\hline $\begin{array}{l}\text { Zostera } \\
\text { japonica }\end{array}$ & $\begin{array}{c}\text { Yellow River, } \\
\text { China }\end{array}$ & $0.69-1.06$ & - & $11.91-30.69$ & - & $\begin{array}{l}\text { (Lin et al. } \\
\text { 2016) }\end{array}$ \\
\hline
\end{tabular}

\section{CONCLUSION}

This study showed the variability of the absorption process of heavy metals $\mathrm{Cu}$ and $\mathrm{Cd}$ in E. acoroides. Metal function in metabolic process influences the absorption process in which $\mathrm{Cu}$ that is known as essential metal is highly absorbed by the plants as shown in the BCF values bigger than one. On the other hand, E. acoroides restricted the absorption of $\mathrm{Cd}$ from the sediments to the roots because this metal is known as non-essential metal. However, once the plants absorb it, they have the ability 
to translocate the metal to other organs such as leaves that can be harvested, thus optimize the phytoextraction process to reduce heavy metal in the environment.

\section{ACKNOWLEDGEMENTS}

This study was funded by a grant from the Fisheries and Marine Science Faculty of Brawijaya University Research Grant 2017. We would like to thank Prof. Akhmad Sabarudin for the valuable comments on the manuscript. We appreciated Supriyadi assistance in preparing the sampling sites map and also to all members of MEXMA Research Group for the discussions to improve this manuscript.

\section{REFERENCES}

Ali, M.M., Ali, M.L., Islam, Md.S. \& Rahman, Md.Z. 2016. Preliminary assessment of heavy metals in water and sediment of Karnaphuli River, Bangladesh. Environmental Nanotechnology, Monitoring \& Management 5: 27-35.

Ambo-Rappe, R., Lajus, D.L. \& Schreider, M.J. 2011. Heavy metal impact on growth and leaf asymmetry of seagrass, Halophila ovalis. Journal of Environmental, Chemical and Ecotoxicology 3(6): 149-159.

Bastami, K.D., Bagheri, H., Kheirabadi, V., Zaferani, G.G., Teymori, M.B., Hamzehpoor, A., Soltani, F., Haghparast, S., Harami, S.R.M., Ghorghani, N.F. \& Ganji, S. 2014. Distribution and ecological risk assessment of heavy metals in surface sediments along southeast coast of the Caspian Sea. Marine Pollution Bulletin 81(1): 262-267.

Bonanno, G. \& Di Martino, V. 2016. Seagrass Cymodocea nodosa as a trace element biomonitor: Bioaccumulation patterns and biomonitoring uses. Journal of Geochemical Exploration 169: 43-49.

Bonanno, G., Borg, J.A. \& Di Martino, V. 2017. Levels of heavy metals in wetland and marine vascular plants and their biomonitoring potential: A comparative assessment. Science of the Total Environment 576: 796-806.

Brown, D.R., Conrad, S., Akkerman, K., Fairfax, S., Fredericks, J., Hanrio, E., Sanders, L.M., Scott, E., Skillington, A., Tucker, J. \& van Santen, M.L. 2016. Seagrass, mangrove and saltmarsh sedimentary carbon stocks in an urban estuary; Coffs Harbour, Australia. Regional Studies of Marine Science 8: 1-6.

Govers, L.L., Lamers, L.P.M., Bouma, T.J., Eygensteyn, J., de Brouwer, J.H.F., Hendriks, A.J., Huijbers, C.M. \& van Katwijk, M.M. 2014. Seagrasses as indicators for coastal trace metal pollution: A global meta-analysis serving as a benchmark, and a Caribbean case study. Environmental Pollution 195: 210-217.

Hidayati, N., Juhaeti, T. \& Syarif, F. 2009. Mercury and cyanide contaminations in gold mine environment and possible solution of cleaning up by using phytoextraction. HAYATI Journal of Bioscience 16(3): 88-94.

Hu, C., Yang, X., Gao, L., Zhang, P., Li, W., Dong, J., Li, C. \& Zhang, Z. 2019. Comparative analysis of heavy metal accumulation and bioindication in three seagrass: Which species is more suitable as a bioindicator? Science of the Total Environment 669: 41-48.
Ismarti, I., Ramses, R., Amelia, F. \& Suheryanto, S. 2017. Kandungan tembaga $(\mathrm{Cu})$ dan timbal $(\mathrm{Pb})$ pada lamun Enhalus accoroides dari Perairan Batam, Kepulauan Riau, Indonesia. Depik 6(1): 23-30.

Lin, H., Sun, T., Xue, S. \& Jiang, X. 2016. Heavy metal spatial variation, bioaccumulation, and risk assessment of Zostera japonica habitat in the Yellow River Estuary, China. Science of The Total Environment 541: 435-443.

Lin, Y.C., Chang-Chien, G.P., Chiang, P.C., Chen, W.H. \& Lin, Y.C. 2013. Multivariate analysis of heavy metal contaminations in seawater and sediments from a heavily industrialized harbor in Southern Taiwan. Marine Pollution Bulletin 76(1-2): 266-275.

Llagostera, I., Perez, M. \& Romero, J. 2011. Trace metal content in the seagrass Cymodocea nodosa: Differential accumulation in plant organs. Aquabotic Botany 95(2): 124-128.

Nguyen, X.V., Tran, M.H. \& Papenbrock, J. 2017. Different organs of Enhalus acoroides (Hydrocharitaceae) can serve as specific bioindicators for sediment contaminated with different heavy metals. South African Journal of Botany 113: 389-395

Ooi, J.L.S., Kendrick, G.A., Van Niel, K.P. \& Affendi, Y.A. 2011. Knowledge gaps in tropical Southeast Asian seagrass systems. Estuarine Coastal and Shelf Science 92(1): 118-131.

Riosmena-Rodríguez, R., Talavera-Sáenz, A., Acosta-Vargas, B. \& Gardner, S.C. 2010. Heavy metals dynamics in seaweeds and seagrasses in Bahía Magdalena, BCS, México. México Journal of Applied Phycology 22(3): 283-291.

Rosalina, R., Herawati, E.Y., Musa, M., Sofarini, D., Amin, M. \& Risjani, Y. 2019. Lead accumulation and its histological impact on Cymodecea serrulata seagrass in the laboratory. Sains Malaysiana 48(4): 813-822.

Saher, N.U. \& Siddiqui, A.S. 2016. Comparison of heavy metal contamination during the last decade along the coastal sediment of Pakistan: Multiple pollution indices approach. Marine Pollution Bulletin 105(1): 403-410.

Sari, S.H., Harlyan, L. \& Yona, D. 2018. Potential mangrove species in Porong River Estuary as inhibiting agent of heavy metal $(\mathrm{Pb}, \mathrm{Cu}$ and $\mathrm{Zn})$ pollution. Pertanika Journal of Tropical Agricultural Science 41: 271-286.

Schlacher-Hoenlinger, M.A. \& Schlacher, T.A. 1998a. Differential accumulation patterns of heavy metals among the dominant macrophytes of a Mediterranean seagrass meadow. Chemosphere 37(8): 1511-1519.

Schlacher-Hoenlinger, M.A. \& Schlacher, T.A. 1998b. Accumulation, contamination, and seasonal variability of trace metals in the coastal zone - patterns in a seagrass meadow from the Mediterranean. Marine Biology 131(3): 401-410.

Sidi, N., Aris, A.Z., Mohamat Yusuff, F., Looi, L.J. \& Mokhtar, N.F. 2018. Tape seagrass (Enhalus acoroides) as a bioindicator of trace metal contamination in Merambong shoal, Johor Strait, Malaysia. Marine Pollution Bulletin 126: 113-118.

Sugiyanto, R.A.N., Yona, D. \& Kasitowati, R.D. 2016. Analisis akumulasi logam berat $(\mathrm{Pb})$ dan Kadmium $(\mathrm{Cd})$ pada lamun Enhalus acoroides sebagai agen fitoremediasi di Pantai Paciran, Lamongan. Seminar Nasional Perikanan dan Kelautan VI Tahun 2016. Malang: Brawijaya University. 
Suwandana, E., Kawamura, K. \& Soeyanto, E. 2011. Assessment of the heavy metals and nutrients status in the seawater, sediment and seagrass in Banten Bay, Indonesia and their distributional patterns. Journal of Fisheries International 6(1): 18-25.

Thangaradjou, T., Raja, S., Subhashini, P., Nobi, E.P. \& Dilipan, E. 2013. Heavy metal enrichment in the seagrasses of Lakshadweep group of islands - a multivariate statistical analysis. Environmental Monitoring Assessment 185(1): 673-685.

Thangaradjou, T., Nobi, E.P., Dilipan, E., Sivakumar, K. \& Susila, S. 2010. Heavy metal enrichment in seagrasses of Andaman Islands and its implication to the health of the coastal ecosystem. Indian Journal of Marine Science 39: 85-91.

Timofeeva, S.S., Ulrikh, D.V. \& Timofeev, S.S. 2017. Phytomining perspectives in rehabilitation of mining and industrial areas of South Ural. Earth and Environmental Science 66(1): 1-5.

van der Ent, A., Baker, A.J., Reeves, R.D., Chaney, R.L., Anderson, C.W., Meech, J.A., Erskine, P.D., Simonnot, M.O., Vaughan, J., Morel, J.L. \& Echevarria, G. 2020. Agromining: farming for metals in future? Environmental Science and Technology 49: 4773-4780.

Yoon, J., Cao, X., Zhou, Q. \& Ma, L.Q. 2006. Accumulation of $\mathrm{Pb}, \mathrm{Cu}$, and $\mathrm{Zn}$ in native plants growing on a contaminated Floride site. Science of The Total Environment 368(2-3): 456-464.
Zakhama-Sraieb, R., Sghaier, Y.R., Hmida, A.B., Cappai, G., Carucci, A. \& Charfi-Cheikhrouha, F. 2015. Variation along the year of trace metal levels in the compartments of the seagrass Posidonia oceanica in Port El Kantaoui, Tunisia. Environmenat Science and Pollution Research 23(2): 1681-1690.

Defri Yona*, Syarifah Hikmah Julinda Sari \& Ruli Hikmah Safitri Fisheries and Marine Science Faculty

Universitas Brawijaya

Jalan Veteran Malang, 65145

Indonesia

Defri Yona* \& Syarifah Hikmah Julinda Sari

Marine Research Exploration and Management (MEXMA)

Research Group

Universitas Brawijaya

Jalan Veteran Malang, 65145

Indonesia

*Corresponding author; email: defri.yona@ub.ac.id

Received: 12 March 2019

Accepted: 7 April 2020 